DOI https://doi.org/10.18551/rjoas.2018-11.39

\title{
DEVELOPING THE ADDED VALUE OF CORN CHIPS AS WAY OF IMPROVING THE COMMUNITY ECONOMY IN GORONTALO PROVINCE OF INDONESIA
}

\author{
Hasan A.M.* \\ Department of Biology, Faculty of Mathematics and Natural Sciences, \\ University of Negeri Gorontalo, Indonesia
}

Halid A.

Faculty of Agriculture, University of Negeri Gorontalo, Indonesia

\author{
Ahmad L. \\ Department of Agricultural Technology, Faculty of Agriculture, \\ University of Negeri Gorontalo, Indonesia
}

\begin{abstract}
Hasdiana
Department of Craft Engineering, Faculty of Engineering, University of Negeri Gorontalo, Indonesia
\end{abstract}

Ilato $\mathbf{R}$.

Department of Administration and Public Policy, Faculty of Economy and Business, University of Negeri Gorontalo, Indonesia

*E-mail: transbahasa.ilmiah@gmail.com

\begin{abstract}
The objective of this study is to create the model for the development of corn-based products. The ultimate objectives of this study is: 1) the availability of development and utilization of appropriate technology for corn processing products to be adopted by industry; 2 ) the increase of added value for each actor within the value chain and community as the economic multiplier effect in Gorontalo province.The method used in this study is quantitative descriptive method which encompasses desk study, secondary data analysis, workshop and meeting with related stakeholders, develop the design of the study for each value chain actor, field visit and in-depth interview, focus group discussion, presentation and findings discussion to formulate the master plan and the model for the development of corn commodity. The conclusion of this study is 1) benefit of chips very dependant on the type of packaging; 2) the advantages of chips are increasingly improved; 3 ) based on the results of the organoleptic test seen from the aroma, taste, texture and the most preferred color is Balado.
\end{abstract}

\section{KEY WORDS}

Corn chips, economic value, community, public service.

Gorontalo Province is known as the maize province that optimistically has the program of one-million-ton maize product achievement in a year to support the national food security. In 2011 there was an extension of maize farmland by 3.500 hectares, and this then had increased the production of maize around 245.000 ton, and that time the product of maize could reach 600.000 tonnes. Besides, as an attempt to increase the maize production, the Government of Gorontalo Province also has attempted various ways including through the improvement of the capacity of the elucidator, the use of the qualified high yield seed and the provision of fertilizer. As stated by Isa (2012), the maize production in Gorontalo from time to time has been increasing in which it is predicted that each maize crop could reach around $65 \%$, and $35 \%$ is in the form of wastes such as stalk, leaves, husk, and stem of maize ear. 
In addition, to fulfill the daily needs of society in Gorontalo, maize also can be processed for a variety of products such as maize steak, maize oil, maize meal, livestock feed, fish feed, and many more. Moreover, the maize grains can be processed into various products, and the waste of maize is also used to be various products such as the ruminant feed and organic fertilizer. The stem of maize ear, furthermore, can be processed to be the charcoal briquette and the husk of maize can be processed to be a flower, toffee wrapping, and starting product of clothes, tablecloth, and many more unique products.

As revealed by a survey, the maize grains in Gorontalo are commonly used as daily food and sold in other neighbor countries or provinces. Usually, the maize grains have not been processed to be other processed products that can improve the economic values from the products. As an illustration, the ratio of the price of one kilogram of maize grains is Rp. 2.800 and when it has been processed to be the livestock feed, then the price can be five times higher than the initial price. By processing the maize grains to be basic livestock feed, it is potential to improve the economical values of the product.

Economic welfare growth depends on the capacity to innovate, to produce sustainably high value-added products which cannot be easily imitated by others. This should be supported by the progressing target, implementation of appropriate technology, developing better quality products and better production process as the foundation for the regional, even international economy in this modern era.

Agriculture sector plays a significant role in the country's economic development, as Indonesia is an agricultural country. Economic development heavily relied on agricultural and agricultural-based industry or agroindustry. Within the agribusiness system, agroindustry is one of the sub-systems which together with other sub-systems shaped the agribusiness. One of the efforts to develop the product from the agricultural sector is by increasing the added value of its products. This can be done by linking the agriculture with industry/processing industry or services in the economic sector [3][4].

Gorontalo province is currently trying to boost its maize commodity, from cultivation to development of its processed products. The maize production in Gorontalo province increases by $7.58 \%$ in 2014 compared to the previous year which was only 719,787 tons [4]. As the featured product from Gorontalo, the added value of maize into various processed products is needed through the involvement of small and medium scale industries. Processing industries of agriculturalproduction will increase the economic value of the products.

One of the popular agricultural product processing industries is corn-based processing industry. There are quite several small-scale corn-based processing industries, such as corn chips, corn flour, popcorn, corn crackers, and fried corn. This corn processing industry process locally produced corn with limited market coverage. In addition, there are also several large companies which produce the maize flour, corn-based noodle, and corn-based snacks such as corn flakes, tortilla chips, and popcorn [6][7].

The objective of this study is to create a model for the development of corn-based products. The ultimate objectives of this study are: 1) the availability of development and utilization of appropriate technology for corn processing products to be adopted by industry; 2) the increase of added value for each actor within the value chain and community as the economic multiplier effect in Gorontalo province.

\section{LITERATURE REVIEW}

Corn Commodity. Corn is the second food source of carbohydrates after rice, essential for food security. Corn also plays an important role in the animal feed industry and the food industry. In Anonim (2012) it was explained that in the past five years, the need for national maize for feed, food and beverage industry materials increased $\pm 10 \%-15 \% /$ year. Based on the order of staple food in the world, corn is the third after wheat and rice (Directorate General of Food Crops, 2012). Corn plants have many uses. Almost all parts of the plant can be utilized, for example, 1) Young leaves: cake wrappers (sticky dodol, corn leaf flowers, fabric fibers); 2) Young stems and leaves: animal feed; 3) Old stems and leaves; green 
manure or compost; 4) Dry stems and leaves for firewood. According to Anggraeny et al. (2006) corn waste from stems ranged from 55.4-62.3\%, from leaves $22.6-27.4 \%$ and from klobot between 11.9-16.4\%; 5) Corn stalks; pulp (paper material); 6) Young corn fruits: cakes, vegetables, bakwan; and 7) Old corn kernels; substitute for rice, marning, pastries, animal feed, flour, rice noodles, mixtures of ground coffee, biscuits, corn bread, popcorn, animal feed, raw materials for beer industry, pharmaceutical industry, dextrin, adhesives, textile industry.

Corn Farmers Society. The community of corn farmers is a community that has a basic business and livelihood as a corn farmer. Farmers' lives are synonymous with the lives of people in rural areas so that the corn farming community is also called a farmer or peasant. Corn farmers are human resources that need to be considered because part of agricultural producers in a region Commodities produced by corn farmers are corn (Zea mays) which can grow normally in altitude areas 0-1300 above sea level (Mindalan 2007). This infographic characteristic is characteristic of the Indonesian region, including in Gorontalo Province, especially in Boalemo District, so it can be concluded that corn is a plant that is very suitable in developing productive commodities through various community empowerments, especially corn farming communities.

Corn Chips. Corn is one of the important types of food with complete nutritional content such as rice. According to EIRI (Engineers India Research Institute), the composition of nutrients contained in each corn seed is carbohydrates 8-10\%, Proteins $9-7 \%$, starch 50 $60 \%$, Fat $10-15 \%$, water in small amounts, sugar $10 \%$ and ash $\pm 3 \%$. This chemical composition makes corn as the second food source after rice.

In Indonesia, corn is not only consumed in the form of whole corn seeds which are processed by boiling, burning or added to vegetables but as technology advances, processed corn products are also increasingly diverse. One of them is corn chips.

Corn chips are one of the corn processing industries which are very potential to be developed in rural areas because the manufacturing process is very simple, high yield and products in the form of raw chips have a long shelf life because of the low moisture content and fat content. Therefore, corn chips is one of the processed products that has been widely known by the community, especially in Java, this is evidenced by the many agro-industries there that make corn chips as one of the starting products, among others, as mentioned by Hadi (2010) in his study stated that for the case study in the Pandan Wangi sub-district, Blimbing District, Malang Municipality, the average agro-industry for corn chips earned a

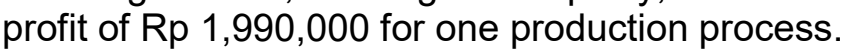

The data from the Development Studies Association (2008) obtained from statistical data in 2006 that 12.2 million people living in Ethiopian urban areas with an average of 5 family members represented around 2.5 million families; only 2.5 percent of these families can meet the need for chips with the potential demand for 62,500 families. With a conservative assumption that of 1 kilogram of corn chips consumed per family per week at a lower price, the annual demand will increase to 3000 tons. Analysis of this demand increased when the public and requests from hotels, restaurants and international cafes were added to the calculation.

\section{METHODS OF RESEARCH}

The method used in this study is quantitative descriptive method which encompasses desk study, secondary data analysis, workshop and meeting with related stakeholders, develop the design of the study for each value chain actor, field visit and in-depth interview, focus group discussion, presentation and findings discussion to formulate the master plan and the model for the development of corn commodity.

Activities: 1) identification of potentially applicable corn processing technology for the industry, 2) engineering of the appropriate technology and economic analysis and technical analysis for the utilization of appropriate technology engine, 3) business feasibility analysis, added value analysis and projection of multiplier effect, 4) stakeholder and institutional mapping, SWOT analysis, strategy formulation for the strengthening of value chain strategy 
for various corn processing products, 5) formulation of intervention activities to increase production, 6) socialization and evaluation toward the implementation of value chain result/formulation of strategy for intervention activities, increasing the production of various corn-processing products, replication of various corn processing-based industries to other areas in Gorontalo, 7) research roadmap initiated by previous study.

\section{RESULTS AND DISCUSSION}

Total Production Cost and the Sales Volume of Corn chips Product for 2015-2017. The data on the production cost of corn chips fluctuated monthly and annually. This production cost fluctuation is largely influenced by a number of produced products. The average fluctuation in each year consecutively is $15 \%$ in $2015,7 \%$ in 2016 , and $3 \%$ in 2017 . The production cost steadily increased annually along with the increase in sales volume. The average increase of production cost on the period of $2015-2017$ is $79 \%$; whereas the average increase of sales volume of corn chips annually for a similar period is $85 \%$.

The average range of monthly production cost is from Rp. 900.000 to Rp. 1.500 .000 from 2015 to 2017. The average sales also increase from Rp. 1.500 .000 to Rp. 2.700 .000 during a similar period. The comparison of production cost against the sales volume for each month ranges from $67.75 \%$ to $77.9 \%$. The sales volume value is higher than the production cost. Thus, the income for this corn chips production stays positive over the years.

Table 1 - Total production cost and the sales volume of corn chips product for 2015-2017

\begin{tabular}{|c|c|c|c|c|c|c|}
\hline \multirow{2}{*}{ Month } & \multicolumn{6}{|c|}{ Year } \\
\hline & $\begin{array}{c}\text { Production } \\
\text { cost }\end{array}$ & Sales & $\begin{array}{l}\text { Production } \\
\text { cost }\end{array}$ & Sales & $\begin{array}{c}\text { Production } \\
\text { cost }\end{array}$ & Sales \\
\hline January & 2.914 .972 & 4.403 .800 & 8.462 .849 & 14.817 .400 & 12.800 .850 & 23.695 .900 \\
\hline February & 3.461 .676 & 5.551 .000 & 8.883 .372 & 15.501 .800 & 11.873 .569 & 20.982 .100 \\
\hline March & 2.856 .185 & 4.358 .000 & 8.412 .812 & 14.607 .400 & 14.790 .457 & 28.270 .800 \\
\hline April & 4.168 .967 & 6.698 .200 & 11.353 .687 & 20.486 .700 & 10.749 .833 & 19.042 .700 \\
\hline May & 2.438 .936 & 3.891 .600 & 8.910 .574 & 18.585 .800 & 15.197 .112 & 30.696 .800 \\
\hline June & 5.120 .296 & 9.031 .600 & 10.452 .950 & 20.004 .500 & 8.272 .321 & 12.894 .500 \\
\hline July & 5.833 .965 & 10.607 .200 & 4.203 .190 & 8.078 .800 & 10.134 .201 & 16.996 .900 \\
\hline August & 3.844 .406 & 6.575 .600 & 8.297 .840 & 13.731 .000 & 14.258 .374 & 26.322 .700 \\
\hline September & 5.019 .945 & 8.191 .000 & 9.536 .060 & 16.407 .300 & 13.669 .801 & 24.178 .900 \\
\hline October & 3.633 .890 & 5.809 .800 & 8.785 .913 & 15.244 .700 & 12.461 .701 & 19.778 .500 \\
\hline November & 3.613 .152 & 5.812 .600 & 8.207 .503 & 13.540 .800 & 13.901 .187 & 25.195 .900 \\
\hline December & 6.001 .766 & 11.113 .400 & 8.848 .623 & 12.223 .500 & 11.931 .132 & 18.883 .500 \\
\hline Total & 48.908 .157 & 82.043 .800 & 104.355 .373 & 183.229 .700 & 150.040 .538 & 266.939 .200 \\
\hline
\end{tabular}

Source: processed secondary data, 2018.

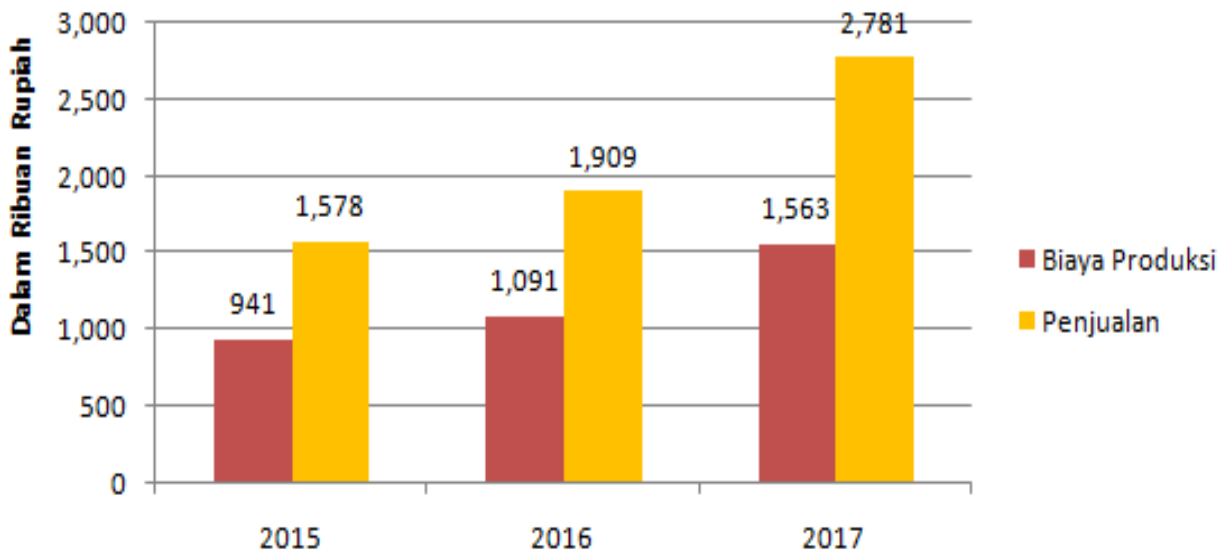

Figure 1 - Comparison graphic of average production cost and sales volume for the period of 2015-2017 (Source: processed secondary data source, 2018) 
The income value for corn chips production for the period of 2015-2017. As seen in Table 2, it shows that the monthly income from corn chips production stays positive over the years. The monthly income is influenced by production cost and total sales of the product. The lowest income per month on average is Rp. 1.500.000; and the highest income per month is Rp. 11.000.000. The highest average increase of income per month for the period of $2015-2017$ is $27.7 \%$; whereas the lowest average income per month from this product for a similar period is $12.4 \%$.

Table 2 - The income value for corn chips production for the period of 2015-2017

\begin{tabular}{cccc}
\hline Month & \multicolumn{3}{c}{ Income/year (in Rupiah) } \\
\hline January & 1.488 .828 & 2016 & 2017 \\
February & 2.089 .324 & 6.354 .551 & 10.895 .050 \\
March & 1.501 .815 & 6.618 .428 & 9.108 .531 \\
April & 2.529 .233 & 6.194 .588 & 13.480 .343 \\
May & 1.452 .664 & 9.133 .013 & 8.292 .867 \\
June & 3.911 .304 & 9.675 .226 & 15.499 .688 \\
July & 4.773 .235 & 9.551 .550 & 4.622 .179 \\
August & 2.731 .194 & 3.875 .610 & 6.862 .699 \\
September & 3.171 .055 & 5.433 .160 & 12.064 .326 \\
October & 2.175 .910 & 6.871 .240 & 10.509 .099 \\
November & 2.199 .448 & 6.458 .787 & 7.316 .799 \\
December & 5.111 .634 & 5.333 .297 & 11.294 .713 \\
\hline Total & 33.135 .600 & 3.374 .877 & 6.952 .368 \\
\hline
\end{tabular}

Source: processed secondary data, 2018.

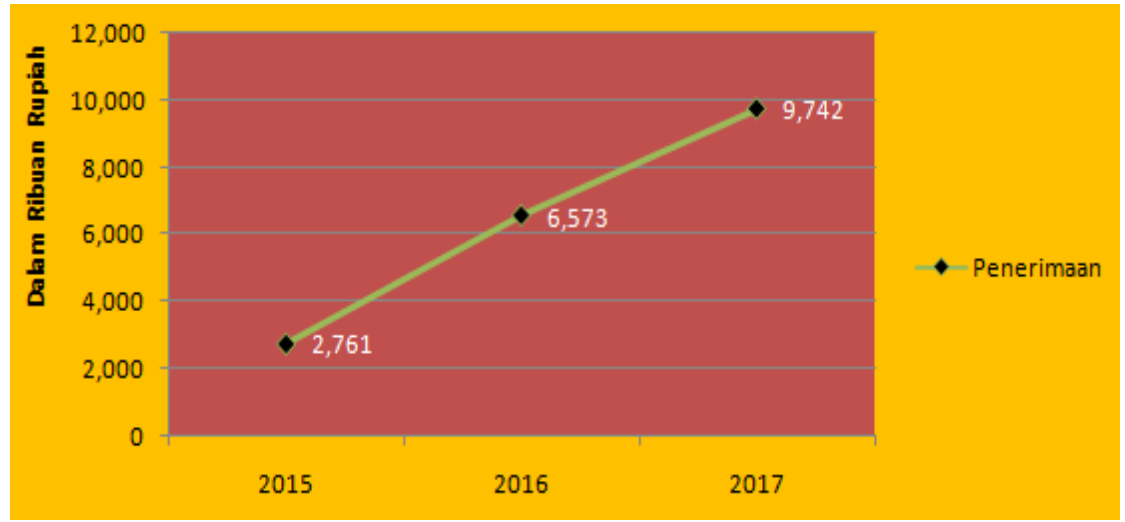

Figure 2 - The trend of the average increase in income in the period of 2015-2017

(Source: processed secondary data, 2018)

For each month, the average income is about Rp. 2.700 .000 to Rp. 9.700 .000 from 2015 to 2017. In 2016, the average income increases by $138 \%$ compared to the previous year; meanwhile, in 2017, the increase is $48 \%$ compared to 2016 . The average income increases by $93 \%$ during the period of $2015-2107$. This steady positive increase of income indicates that the corn chips product is favored by the consumers and can increase the welfare of the small-scale industry that works in producing these corn chips.

As seen in Figure 3 below, the total production cost, total sales volume, and income from these corn chips during the period of 2015-2017, the total production cost annually increases with linear pattern toward the sales and income. This brings the positive influence for the improvement of welfare level through improvement of performance of the small-scale industries which produce these corn chips.

The level of sales of these small-scale industries which produce these corn chips is very profitable and promising as the economic locomotive for the products in Gorontalo. The value of sales is above all the cost components, which in turn yields positive returns. 


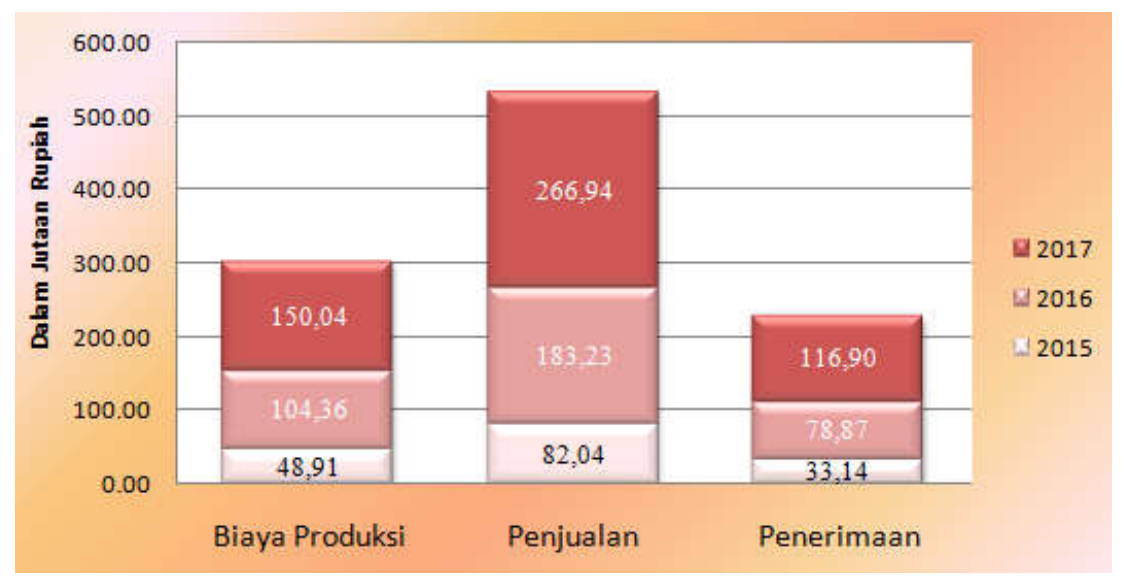

Figure 3 - Graphic of total value development for the period of 2015-2017

(Source: processed secondary data, 2018)

Organoleptic Analysis. The organoleptic analysis is one of the analyses used to determine whether a product is suitable or not, especially food products are preferred or not liked. The results of this assessment will be used as a basis for the chips industry to be developed or not because the organoleptic aspect has been accepted by consumers. The results of the organoleptic analysis of corn chips were carried out with 5 testing scales, namely: $5=$ very like, $4=$ like, $3=$ Rather like, $2=$ less like it, $1=$ Don't like the picture below

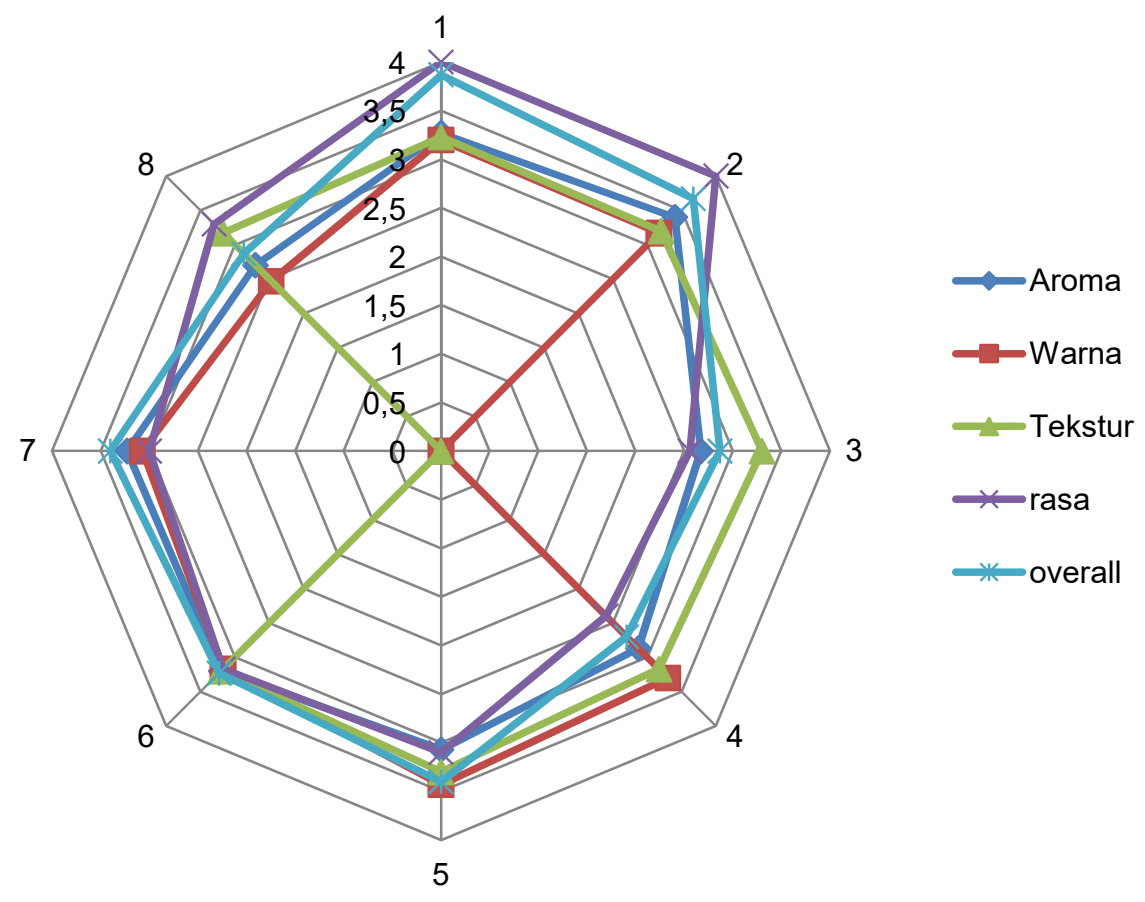

Note: 1 = Balado Taste, 2 = Spicy Sweet Balado Flavored Chips, $3=$ Sweet Cheese Flavor, $4=$ Salted Cheese Flavor, 5 = Empty Flavored Corn Flavor, $6=$ Roasted Chicken Flavored Chips, $7=$ Roast Cow Flavor, $8=$ Taste Flavored Chips

Figure 4 - Spider diagram for organoleptic corn chips with 8 flavor variants

Organoleptic testing showed that corn chips for flavor parameters (purple) with Balado flavored corn chips and sweet spicy balado occupied the outermost point on scale 4 on the spider diagram above. Likewise, for the overall organoleptic parameters, it shows values in the scale range above 3 for the two variants. This value can be interpreted that the average consumer "likes" the aroma, taste, texture, color and taste of corn chips with this flavor 
variant. Unlike the chips with sweet cheese flavors, salted cheese andbalado flavor, the results of the average rating for the overall parameters are in the range of 2 and above. This value can be interpreted that consumers give a "rather like" rating, as well as the color, taste, aroma, and texture of corn chips for the three formulas. When observed, the panelist's assessment of all corn chips is in the scale of 3 (rather like) on all test parameters except for the salted cheese flavor, sweet cheese flavor and barbeque flavor with overall parameters. Nevertheless, the results of testing of corn chips with different flavor variants organoleptically did not show a significant difference for all test parameters.

Analysis of Production Cost Correlation with the Sales of Corn Chips Product. The correlational analysis is carried out to investigate whether there is a correlation between the production test and the level of sales of these corn chips product. This test is administered using the Pearson product moment correlation test, where different annual financial data are used. This test is to ensure the significant correlation between production cost and sales of the corn chips product. The result of this test is presented in Table 3 below.

Table 3 - Average value and Deviation Standard

\begin{tabular}{cccc}
\hline Variables & Total & Average & Std. deviation \\
\hline Production cost & 36 & 8425112,97 & 3856708,430 \\
Sales & 36 & 7,1399 & 0,32043 \\
\hline
\end{tabular}

Source: processed secondary data, 2018.

The average value of production cost for corn chips product is compared against the standard deviation value. As seen in Table 3 above, the average value 8425112,97; whereas the standard deviation value is 3856708,430 . This average value is higher than the standard deviation value. Hence, it can be said that the data is appropriate to be analyzed. Similarly, the average value of sales variable is 7,1399 with the standard deviation value of 0,32043 . The average value is larger than the deviation standard value, thus, worthy of analysis.

Table 4 - Summary of the Correlational test result

\begin{tabular}{|c|c|c|c|}
\hline & $r$-count $\left(t_{\text {table }}= \pm 1,975\right)$ & Sig. (p-value) & notes \\
\hline Production cost* sales & 0,775 & 0.000 & Significant \\
\hline
\end{tabular}

Source: processed secondary data, 2018.

The result of the correlation test of the production cost and the sales yields the r-count of 0,775 with the significance level of 0,000 . The $r$-count 0,775 describes that there is a strong and positive correlation between the production cost and sales of corn chips product. This increase in corn chips production is also followed by the positive increase in sales. Thisis statistically proven that there is a significant correlation between production cost and sales, where the $p$-value 0,000 is smaller than alpha 0,05 . Therefore, it also indicates that the production cost of corn chips also influences the increase of sales of the product and impacts on the increase in income. This result indicates that production cost and the sales of the corn chips are promising for the community to utilize this corn commodity and turn it into corn chips. The corn commodity as the leading commodity in Gorontalo can be utilized into corn chips, which have been done by these small-scale industries to increase their economic welfare.

Normality data test of the production cost and sales variables of corn chips. Normality test is to test whether data or the investigated variables or the developed model has normal or abnormal distribution. In linear correlation, the data distribution is expected to have to have a normal distribution. The normality test is conducted using the Kolmogorov-Smirnov test, where the test is carried out and proven with the asymptotic significance. Asymptotic significance value which larger than 0.05 , shows that the variables or observed data have a normal distribution, and vice versa. The Kolmogorov-Smirnov test result is presented in Table 5 below. 
Table 5 - The result of data normality test

\begin{tabular}{llll}
\hline Variables & Asymptotic Sig. & Alpha $(\alpha)$ & Notes \\
Production cost & 0.200 & 0.05 & Normal \\
Sales & 0.200 & & Normal \\
\hline
\end{tabular}

Source: Processed data, 2018.

Table 5 above shows that the asymptotic significance value of production cost and marketing is more than alpha $0.05(>5 \%)$. Therefore, it can be said that the variables used in the correlation model meet the normal assumption and appropriate to be used.

Linearity Test of Production Test Variable and Sales price of Corn Chips Product. The linearity test is conducted to see whether there is a linear correlation pattern between the variable or insignificant. The test is carried out using the Test for Linearity with the significance level of 0.05 . Two variables can be said to have a linear correlation when the significance level is less than 0.05 . The linearity test of the variable is shown in Table 6 below.

Table 6 - Linearity test of the variable

\begin{tabular}{|c|c|c|c|}
\hline & Linearity & Alpha ( $\alpha)$ & notes \\
\hline Production cost * sales price & $0.000<0.05$ & & Linier \\
\hline
\end{tabular}

Source: processed data, 2018.

From Table 6 above on the linearity test result above, it is known that the significance value on the linearity is 0.000 . The significance value of the test for linearity is smaller than the alpha value $(0.000<0.05)$. Therefore, it can be concluded that there is a linearity correlation between the production cost and sales price.

Table 7 - Tests of Normality

\begin{tabular}{lllllll}
\hline & \multicolumn{2}{l}{ Kolmogorov-Smirnov $^{2}$} & & \multicolumn{2}{l}{ Shapiro-Wilk } \\
& Statistic & Df & Sig. & Statistic & df & Sig. \\
\hline Production cost & .116 & 36 & .200 & .944 & 36 & .066 \\
Log_Sales price & .112 & 36 & $.200^{*}$ & .906 & 36 & .005 \\
\hline
\end{tabular}

*. This is a lower bound of the true significance.

a. Lilliefors Significance Correction.

Table 8 - ANOVA Table

\begin{tabular}{|c|c|c|c|c|}
\hline & & & Sum of Squares & Df \\
\hline Production cos & *Between Groups & (Combined) & 32.563 & 202 \\
\hline \multirow{4}{*}{ Log_sales price } & & Linearity & 29.638 & 1 \\
\hline & & Deviation from Linearity & 2.925 & 201 \\
\hline & Within Groups & & .132 & 35 \\
\hline & Total & & 32.695 & 237 \\
\hline
\end{tabular}

Table 9 - ANOVA Table

\begin{tabular}{llll}
\hline & & Mean Square & $\mathrm{F}$ \\
\hline Between Groups & (Combined) & .161 & 42.624 \\
& Linearity & 29.638 & 7836.628 \\
& Deviation from Linearity & .015 & 3.847 \\
Within Groups & & .004 & \\
\hline Total & & & \\
\hline
\end{tabular}

Table 10 - ANOVA Table

\begin{tabular}{|c|c|c|}
\hline & & Sig. \\
\hline \multirow[t]{3}{*}{ Between Groups } & (Combined) & .000 \\
\hline & Linearity & .000 \\
\hline & Deviation from Linearity & .000 \\
\hline \multicolumn{3}{|l|}{ Within Groups } \\
\hline Total & & \\
\hline
\end{tabular}

Within Groups 


\section{CONCLUSION}

The conclusion of this study is 1) benefit of chips very depending on the type of packaging; 2) the advantages of chips are increasingly increasing; 3 ) based on the results of the organoleptic test seen from the aroma, taste, texture and the most preferred color is Balado.

\section{ACKNOWLEDGMENTS}

Researchers would like to thank the parties who have funded this research:

- Directorate General of Strengthening Research and Development of the Ministry of Research and Technology in Jakarta, contract PUSN 2018 number: 249/UN47.D/PL/2018 at $19^{\text {th }}$ February 2018;

- Pohuwato Regency Industry and Trade Service, Recommendation number: 518/DPPK\&UKM-PHWT/256/2017;

- Gorontalo Regency Industry and Trade Service, Recommendation number: 800/DPP/VI/215/2017.

\section{REFERENCES}

1. Suyono, HaryonodanHaryanto, R. 2007. Pedoman Pembentukandan Pengembangan Pemberdayaan Keluarga - POSDAYA.BalaiPustaka.

2. Hasan, M. Ani. 2011. Aktualisasi Program Pemberdayaan Masyarakat Pedesaan Guna Peningkatan Pertumbuhan Ekonomi Daerah Dalam Rangka Ketahanan Nasional. Laporan Penelitian.

3. Muhammad, Fadel. 2012. Indonesia EffortsTowards the Leading of Maize Agribusiness and Agroindustry in the World by 2025.Paparandisampaikanpada International Maize Conference. Gorontalo 22-24 November 2012.

4. Ahmad, Lisna. 2011 dan 2012. Analisissifat Fisiokimiadan Respon Konsumenterhadap Tepung Pudding InstanHasil Formula Siteping Jagungdan Karagenan. Laporan Penelitian. Gorontalo: Lemlit UNG.

5. Kajian Kebijakan Agribisnis Komodistas Unggulan Daerah di Provinsi Gorontalo, Balai Pengkajian Teknologi Pertanian (BPTP) Gorontalo, 2012

6. Halid, Amir. 2010. Dampak Agropolitan Jagung Terhadap Penurunan Angka Kemiskinan di Kabupaten Gorontalo;.LaporanPenelitian

7. Hasan, A.M., R. Ilato, A. Haliddan L. Ahmad. 2016. Farmer Empowerment through Prcessing of Maize and Each Waste in To Productive Economic Comodity in Boalemo Regency of Gorontalo. International Journal of Bussiness, Accounting and Management.Vol.1 Issue 3. ISSN 2527-3531: 53-64

8. Halid, Amir, 2014. Pengembangan Profitabilitas Jagung, Idaes Publishing, Gorontalo.

9. Ilato, Rosmandan Bahua, M. Ikbal. 2013. Analisis Rantai Nilai Komoditas Jagungserta Strategi Peningkatan Pendapatan Petani Jagung di PropinsiGorontalo. Penelitian MP3EI 2011-2025). Gorontalo: Lemlit UNG. 